\title{
From Rural to Microfinance Banking: Contributions of Micro Credits to Nigeria's Economic Growth - An ARDL Approach
}

\author{
Prince C. Nwakanma ${ }^{1}$, Ikechukwu S. Nnamdi ${ }^{1} \&$ Godfrey O. Omojefe ${ }^{1}$ \\ ${ }^{1}$ Department of Finance and Banking, University of Port Harcourt, Nigeria \\ Correspondence: Prince C. Nwakanma, Senior Lecturer, Department of Finance and Banking, University of Port \\ Harcourt, Nigeria. E-mail: nwakanma5@yahoo.com
}

Received: April 3, 2014

Accepted: May 1, 2014

Online Published: June 1, 2014

doi:10.5430/ijfr.v5n3p73

URL: http://dx.doi.org/10.5430/ijfr.v5n3p73

\begin{abstract}
Given current emphasis on potentials of micro credits as a means of addressing poverty alleviation and improved economic growth especially in developing economies, this study seeks to evaluate the nature of long-run relationship and the direction of causality between economic growth and micro credits disbursed by private sector led micro finance institutions in Nigeria. Covering the period 1982 - 2011 (30 years), the Autoregressive Distributed Lag (ARDL) technique was employed in analyzing the time series data. The study finds significant long-run relationship between Nigeria's economic growth and micro credits disbursed, while causality runs from economic growth to micro credits (unidirectional). Accordingly, increase in the quantum of micro credits as well as development of long tenured micro credit products are recommended as strategies to enhance the contributions of micro credits to Nigeria's economic growth.
\end{abstract}

Keywords: micro credits, active poor, community enterprise, causality, ARDL

\section{Introduction}

Financial institutions constitute veritable instruments for economic growth of nations. Through the process of financial intermediation, Shaw (1967) argues that financial institutions effectively mobilize and allocate scarce financial resources thereby, facilitating real investment process. This results in increased output growth. Financial economics is replete with evidence of diverse empirical relationships that exist between the financial system (through instrument of credit or other intermediation ratios) and economic growth as well as the directions of causality between them.

Schumpeter (1934) credits spontaneous and rapid growth of nations to innovative entrepreneurship, made possible by the banking system's unparalled capacity to provide credit for entrepreneurship. In the same vein, Shaw (1967), Goldsmith (1969) and Mckinnon (1973) all allude to the fact that financial development facilitates economic growth through increased savings, efficient allocation and investment of financial resources. These studies contend that development of financial markets is a necessary condition for economic growth. To that extent, the level of development and sophistication of any nation's financial markets could significantly be relied on as one of the valuable indicators of level of economic growth.

Over the years and at policy level, Adeyimi (2007) contends that the Nigerian government has been saddled with the primary objective of creating valuable micro finance structures that will not only improve the living standards of the active and entrepreneurial populace, but additionally, provide them with micro credit facilities at relatively lower costs. These are needed to increase the possible range of employment opportunities and through that, enable the active poor contribute to the aggregate and increased growth rate of the economy. Micro finance within the framework of this study is defined as provision of a complete range of financial services - micro credit, micro lease, micro savings, insurance, inclusive of funds transfers to the active and entrepreneurial poor, who ordinarily lack access to conventional deposit money banks' services in order to advance their economic status and assist them become self-employed and economically self dependent. On the other hand, micro credit is conceived as a small credit facility offered to a micro entrepreneur or group of micro-entrepreneurs by a relevant finance institution often without a charge on any preferred security, but predicated on anticipated streams of cash inflows. (Agene, 2011) 
Against this back ground, the government has not only introduced financing schemes that were managed as government agencies over the years but also, crafted certain schemes that compelled the private sector led banking industry to share part of the micro credit expansion pains. In this direction, even the colonial administration in Nigeria initiated micro credit policy measures to enhance access of the enterprising poor to micro finance with the promulgation of the Co-operative Societies Ordinance of 1939. This move was in reaction to the often stringent requirements for credit approvals by conventional commercial banking institutions resulting from their usual high-risk perception of micro enterprises as well as the perceived high cost of administering such largely scattered micro credits. Adeyemi (2007) as well as Agene (2011) further observe that public policy attempts at enhancing the active poor's access to micro credits include the establishment of various development finance institutions and agencies by the Nigerian government. These include the Nigeria Agricultural, Co-operative and Rural Development Bank in 1973, charged with the responsibility of providing agricultural and rural based credits in the country, the Agricultural Credit Guarantee Scheme fund of 1978, established to mitigate varied forms of agricultural risks to which farmers are exposed. Various State supervised small scale credit schemes came on stream including the people's bank which was established in 1989. Other state ventures in this regard include various phases of Small and Medium Scale Enterprises Schemes (SMEs), as well as the National Economic Recovery Fund (NERFUND). To complement these state policies and efforts, the federal government initiated through the private sector-led banking enterprise, various schemes with the fundamental objective of improving grass root financial intermediation and inclusion hoped to fully integrate the active and enterprising Nigerian poor into the financial system. These efforts gave rise to the Rural Banking programme in 1982. The programme compelled all the existing commercial banks to open specifically allocated number of rural branches on periodic basis and ensure prioritized allocation of credits to agricultural and Micro ventures within their operating environments.

In 1986 however, Nigeria adopted the Structural Adjustment Programme (SAP), which basically aimed at transforming the economy into a market-led economy thereby, minimizing state controls. By 1992, following the phased implementation of SAP and liberalization policies within a market-led economy, sectoral allocation of credits was abolished as well as other direct control measures. The government however, initiated the Community Banking Programme, which provided for community ownership of that category of microfinance institutions with relatively lower capital base requirements. The scheme was expected to mobilize local deposits for significant on-lending to micro ventures therein. Dauda (2007), notes that the community banking operators unfortunately followed the lending pattern of conventional commercial banks. They advanced relatively more credits to short term self-liquidating general commerce ventures at the expense of the real sectors in the rural/environmental enclaves.

As a result of problems associated with poor credit management, Nwakanma and Nnamdi (2011) observe that the government took some measures to remedy the community banking system. Incidentally, following government policy directives, all surviving community banks were directed to transform to Micro Finance banks by $31^{\text {st }}$ Dec., 2006, with increased minimum capital base requirements. This measure was to ensure enhanced operational strengths of the new micro finance banks as well as their capacity to absorb shocks. The core objective of microfinance banking programme still remains grass root banking and financial inclusion through group lending activities to ensure full financial integration of the enterprising poor. In Nigeria, various economic plans and policy thrusts exist which address strategies for optimal poverty alleviation among the bulk of Nigeria's populace. World Bank (1990) and (1993) comment that citizens are classified as poor and/or very poor if their periodic income or consumption is below US $\$ 370$ and US $\$ 275$ respectively. Like many developing countries, poverty largely prevails in Nigeria going by the various National Living Index Surveys conducted by the Federal Bureau of Statistics. Yunus (2003), Helms (2006) and Adeyemi (2007) argue that micro credits hinge on the premise that the relatively lower amounts of credit needed by the enterprising/active poor for their business inputs are not provided by existing formal financial institutions largely for their failure to meet the institutions' stringent credit standards. This failure consequently, exposes them to the various informal sector exploitative high interest arrangements which continuously erode their profit margins and consequently keep them perpetually poor. On the contrary, only few empirical studies to the best of our knowledge, especially those of Rousseau and Wachtel (2002) and (2011), as well as Nuno (2012) suggest that rapid credit expansion often leads to disincentives to save and invest, ultimately resulting in financial crisis. Irrespective of the contentions of these studies, there is at present, a growing interest in microfinance activities against the background of relatively sparse volume of empirical literature. While our attempt in this study is to contribute to the existing body of knowledge, there is need to explore the extent to which disbursed micro credits have impacted on the productive capacities of the active poor through the contributions of their individual and community enterprises to Nigeria's economic growth using recent data. The above issues therefore constitute the core problem of this study. 
It is anticipated that the findings of this study will not only provide a valuable platform for assessment of long-term relationship and direction of causality between micro credits and Nigeria's economic growth but also, provide basis for policy actions that will facilitate the management of micro credit institutions within Nigeria. Having provided an overview of the subject of microcredit operations in Nigeria, the rest of this paper is dividend into four main parts. The second part provides the theoretical framework and literature review for this study while the third part discusses the organization of data and methodology. The fourth part presents the results and analysis while the fifth and last part provides the conclusions and policy recommendations.

\section{Theoretical Framework and Literature Review}

Deriving from the broad roles financial institutions play, there is a wide range of agreement a priori, that microfinance institutions largely function to leverage the active poor. For clarity of purpose, this section is divided into three (3) subsections as follows;

\subsection{Theoretical Considerations}

The works of Shaw (1973) and Mckinon (1973), largely demonstrate the supply-leading roles of financial institutions including microfinance ventures in provision of credit facilities that substantially, advance the growth of output thereby, alleviating poverty with respect to the enterprising poor. In a later study, Patrick (1976) provides an enhanced view of financial institutions in a two-way capacity exhibiting both supply-leading and demand following roles in the economic growth process. In this dual functioning role, financial institutions function to induce and service economic growth respectively. In the same manner, Shaw (1976) provides support for financial liberalization policy measures as opposed to repressive financial policy thrusts thus, creating the most enabling environment for financial organizations to contribute to economic growth.

Of further relevance are the Gap and Exigency theses respectively. Nwankwo (1985) demonstrates that while the Gap thesis argues that the accelerated growth of microfinance institutions arose from the funding gap created by negligence on the part of conventional commercial banks for micro credit ventures, the Exigency thesis on the other hand, could be traced to the urgent need perceived by various national governments to jump-start and also, accelerate their economic growth process by empowering the enterprising poor.

Researchers have also, made significant attempts to evaluate the interrelationships and causalities between bank credits to the private sector in general and economic growth of specific countries and/or regions. Studies reveal that causalities could be uni-directional, bi-directional and in some cases, indeterminate without significant long run relationships. In this vein, Aliero, Abdullahi and Adamu (2013), employ autoregressive distributed lag bound approach (ARDL) in evaluating the relationship between banks' private sector credits and economic growth in Nigeria with time series data over a 37 - year period, (1974-2010). The study finds significant long-run relationship between private sector credits and economic growth, but no significant causality between them in either or both directions. The study therefore, concludes that Nigerian banks are playing neither supply-leading nor demand-following roles but conform to the Schumpeterian independent hypothesis stage. It recommends implementation and adoption of more long-term loans for entrepreneurship ventures in Nigeria in place of the prevalence of present short term and self liquidating credit facilities preferred by Nigerian banks.

Murty, Sailaja and Demissie (2012) examine the long-run impact of bank credits on Ethiopia's economic growth. Adopting a multivariate Johansen's co-integration approach on time series data over the period 1971/72 to 2010/11, the results provide evidence of a positive and significant long-run relationship between bank credit and economic growth. The study concludes that private sector bank credits influence economic growth in Ethiopia through efficient resource allocation and domestic capital accumulation. The creation of more money and capital market institutions to deepen intermediation and enhance long-run economic growth is recommended. Contrary to the above position, Nuno (2012) examines the nexus between bank credit and economic growth in the European Union (EU-27). Covering the period 1990 to 2010, the dynamic panel data (GMM - system Estimator) was employed for its superior capacity in solving problems associated with serial correlation, heteroskedasticity and endogeneity which often accompany the explanatory variables employed in studies. The results show that while savings promotes economic growth, inflation and bank credits negatively impact on economic growth. The study concludes that domestic credit boom if not properly managed, has the potential of weakening the banking system because it has inherent capacity to discourage savings accumulation and investment. Further, if uncontrolled, domestic credit boom eventually increases financial pressure through distortion of price of funds and ultimately, creates financial crisis. 


\subsection{Microfinance across the World}

Agene (2011) traces the origins of microfinance to the era of Franciscan Monks who initiated the community based pawnshops in the $15^{\text {th }}$ century and the founders of European credit union movement in the $19^{\text {th }}$ century. However, modern foundations to microfinance business is traced to Muhammad Yunus - "banker to the poor", and founder of the Grameen Bank in Bangladesh. Microfinance operations can induce significant poverty alleviation if objectively funded. Objective funding in this context, implies provision of the right amounts of micro credits needed for their micro ventures at non-exploitative prices - interest rates. Yunus (2003) and (2008) allude to the fact that the enterprising poor need only relatively small amounts of credit for their inputs, which need not be secured if properly administered on individual or preferably group lending basis. The enterprising poor can largely, neither meet the stringent credit requirements of conventional deposit money banks, nor the exploitative conditions of local money lenders that perpetually impoverish them.

Adeyemi (2007) argues that since the poor constitutes the bulk of the population in most developing nations, both government, social entrepreneurs and in some cases, conventional banks have through one programme or the other, attempted to address their financial needs. The study remarks that while government attempts have largely failed, the efforts of social entrepreneurs have only met limited success. Further, deposit money banks largely view venturing into microfinance business as a form of corporate social responsibility. The study highlights some of these efforts as establishment of the Bank for Agriculture and Rural Development in Vietnam, Bank for Agriculture and Agricultural cooperatives in Thailand, as well as the Bank Rakyat in Indonesia. Other attempts by non-governmental organizations include Opportunity International, which commenced lending operations in Columbia in 1971, ACCION International which disbursed its first microcredits in 1973, the Grameen Bank, which commenced microcredit lending operations in Bangladesh in 1976 etc. Apart from the problem of accessing funds for borrowing, microfinance has also, provided the participating poor with the capacity to save and also, patronize other financial services products. In this direction, Seibeil (2000) argues that although the active poor lack access to financial services emanating from the formal financial sector, studies and experience have shown that they are bankable as they have acquired capacities to save, invest, repay loans and even patronize insurance services as a result of improved incomes resulting from microfinance operations. The findings of Quinones and Remenyi, (2000) substantially demonstrate that on the average, house hold units with access to micro credits significantly realize higher incomes as well as asset acquisition relative to households without access to micro credits.

While Agene (2011) enumerates benefits derivable from patronage of microfinance operations as encouragement of financial discipline and control, facilitation of capital accumulation, absence of hidden costs, provision of trust and confidence, as well as easy access to financial services, the disadvantages revolve more around the attendant risks which include asset and liability management risk, inefficiency risk, system integrity risk, regulatory risk, competition risk, general macroeconomic risk as well as political or government risk.

\subsection{Review of Previous Studies}

Microcredit operations have become increasingly popular especially in developing countries. In this direction, formal private sector- led microfinance attempts in Nigeria progressed from Rural Banking in 1982 through Community Banking in 1992 to the present day Microfinance Banking programme which commenced on $31^{\text {st }}$ Dec., 2006 with corresponding operational performance and idiosyncrasies. On the operations of rural banks, Umesi (1981) argues, that most rural branches did not attend to more than fifty (50) customers per day. Further, the branches held largely savings deposits and salary- fed accounts of rural civil servants. The study contends that since civil servants, rural petty traders, artisans and farmers constitute the bulk of rural bank customers, the operations of rural banks are likely to remain unprofitable. Since these caliber of customers lack both the collaterals to borrow and the awareness to invest their funds, they are less likely to take advantage of the wide range of financial opportunities which the rural branches represent.

In a reply to Umesi, Ibene (1981) argues that commercial banks have no reason to complain on rural banking programme. Admitting that the programme entailed significant overhead costs and staffing problems, the study contends that the problems were likely magnified by the participating banks but nonetheless; weigh far less than the price the established commercial banks were expected to bear to justify the course of national financial development. The study further argues that banks' complaints on the ignorance of the rural populace on the potential benefits of bank services is simply a reflection of the arm-chair attitude of rural branch staff who prefer to wait in their offices for "sure money" as opposed to adopting strategic marketing approach to win over, the seemingly ignorant and skeptical customers. The rural branch staff attitude to marketing, the study argues, simply implicates the basic fact that they are yet to understand the dictates of their trade. 
Umoh (1984) evaluates the varied complaints by participating commercial banks in the rural banking scheme and finds them irreconcilable with the large corporate profits declared annually by the participating banks. Recognizing the need for further expansion of the rural banking scheme, the study recommends that the government should apply more of the carrot than stick in order to make the programme more palatable to the participating commercial banks. Even within the banking industry, varied expert and professional opinions prevail. Kuforuji (1985) argues that the pace at which the various phases of the rural banking programme are executed drains corporate resources and could become counter-productive if a moratorium is not urgently observed. At the other extreme however, Adegbite (1985) posits that the rural banking scheme proves profitable and should be continued while asserting that all Wema Bank rural branches report reasonable profits. This position is again, collaborated by Akinrisimi (1986) who asserts that reasonable number of rural branches of International Bank for West Africa were performing better than many urban branches using all performance indicators. In another development, Dauda (2007) evaluates the performance of Nigeria's community banking scheme and observes that deposits generated significantly grew over the period of evaluation (1992 - 2004). The study attributes the deposit growth to improved grass root banking habit. Although their aggregate loan portfolio to agriculture and rural based real sector activities increased nominally over the period, the credit exposures are relatively much lower than their exposure to general commerce, $(19.2 \%$ against $47.6 \%)$. The study remarks that this trend is counter-productive to policy efforts at boosting real sector growth and sustainable economic development in Nigeria.

Recognizing the intermediating capacities of microfinance institutions and tracing their theoretical base to the Gap thesis, Ezirim, Adebayo and Ogunbiyi (2008) explore the operational environment, scope of operations, products and constraints to their operations in Nigeria. The study argues that Nigerian microfinance institutions have limited capital and deposit mobilization capacities relative to established and more sophisticated competing commercial banking institutions. Further constraints include scarcity of skilled personnel, relatively lower level of education and poor banking habits of their clients (in terms of low savings habit and discouraging loan repayment culture). Of relevance also, are their high operational costs and the prohibitive constraints imposed by high cost of modern day technology needed to drive financial services relative to their available capital resources.

Akinboyo (2007) examines the potentials of microfinance institutions drawing from experiences of other countries. The study traces Nigerian government's efforts at providing microcredit opportunities for the enterprising poor. It strongly advocates for microfinance scheme expansion in Nigeria on the basis that it is characteristically, a less complex financing set up and serves as the ultimate strategy for enhancing participation of the enterprising poor with resultant alleviation of their poverty conditions. Okpara (2010) examines the critical factors that induce poverty among the enterprising poor in Nigeria and the extent to which micro credits have assisted in alleviating poverty. The study's selected causative factors for poverty include low profit, high cost of start-up or expansion funds for business and low rate of business growth. Employing two-stage regression technique within a quadratic equation framework, the study finds that in the first or take-off stage of microfinance banking, poverty was observed to have increased, though at a declining rate with increase in micro credits. In the second stage of the study which started from the year 2001, persistent increases in disbursed micro credit facilities are observed to have significantly lowered the poverty index in Nigeria. Consequently, the study calls for policy measures to establish microfinance institutions in every community in Nigeria.

Oluyombo (2011) examines the contributions of microfinance banks to Nigeria's economic growth and employs credits disbursed by the microfinance institutions as a proxy for their operational activities. The study employs the Ordinary Least Squares (OLS) regression technique and finds a weak, though positive relationship between Nigeria's microfinance banking operations and the nation's economic growth. Consequently, it recommends that microfinance institutions should channel very high proportion of their credits to the productive and real sectors of the economy for valuable impact of their operations on Nigeria's economic growth. Sharma and Puri (2013) test the empirical relationship between microfinance banking operations and India's economic growth. Applying correlation and OLS regression techniques on Indian data between the period 2006/7 and 2011/12, the study finds a high correlation coefficient of 0.96 between micro credits and India's economic growth as well as a significant contribution by micro loans to India's gross domestic product over the period of study.

\section{Organization of Data and Methodology}

\subsection{Data and Variable Description}

The relevant data for this study consist of annually aggregated cash related credit exposures of the three private sector-led micro credit programme transitions in Nigeria and real gross domestic product. The programmes covered the periods 1982-1991 for rural banking scheme, 1992 - 2005 for community banking scheme and 2006 up to 2011 
for the current microfinance scheme. Secondary data were sourced from the Statistical Bulletin of Central Bank of Nigeria, presented as table 1 below:

Table 1. Real gross domestic product, total rural, community, microfinance bank credits and aggregate micro credits in Nigeria, 1982 - 2011, (NM)

\begin{tabular}{|c|c|c|c|c|c|}
\hline Year & $\begin{array}{c}\text { Real Gross } \\
\text { Domestic } \\
\text { Product (NM) }\end{array}$ & $\begin{array}{c}\text { Total Rural } \\
\text { Bank } \\
\text { Credits } \\
\text { (NM) } \\
\end{array}$ & $\begin{array}{c}\text { Total Community } \\
\text { Bank Credits (NM) }\end{array}$ & $\begin{array}{l}\text { Total Microfinance } \\
\text { Bank Credits (NM) }\end{array}$ & $\begin{array}{c}\text { Aggregate Micro } \\
\text { Credits (NM) }\end{array}$ \\
\hline 1982 & $246,726.60$ & 39.50 & - & - & 39.50 \\
\hline 1983 & $230,380.80$ & 44.20 & - & - & 44.20 \\
\hline 1984 & $227,254.70$ & 58.20 & - & - & 58.20 \\
\hline 1985 & $253,013.30$ & 114.90 & - & - & 114.90 \\
\hline 1986 & $257,784.40$ & 373.60 & - & - & 373.60 \\
\hline 1987 & $255,997.00$ & 492.80 & - & - & 492.80 \\
\hline 1988 & $275,409.60$ & 659.90 & - & - & 659.90 \\
\hline 1989 & $295,090.80$ & 3721.10 & - & - & 3721.10 \\
\hline 1990 & $472,648.70$ & 4730.80 & - & - & 4730.80 \\
\hline 1991 & $328,644.50$ & 5962.10 & - & - & 5962.10 \\
\hline 1992 & $337,288.80$ & & 135.80 & - & 135.80 \\
\hline 1993 & $342,540.50$ & & 645.50 & - & 654.50 \\
\hline 1994 & $345,228.50$ & & 1220.60 & - & 1220.60 \\
\hline 1995 & $352,646.20$ & & 1129.80 & - & 1129.80 \\
\hline 1996 & $367,218.10$ & & 1400.20 & - & 1400.20 \\
\hline 1997 & $377,830.80$ & & 1618.80 & - & 1618.80 \\
\hline 1998 & $388,468.10$ & & 2526.80 & - & 2526.80 \\
\hline 1999 & $393,107.20$ & & 2958.30 & - & 2958.30 \\
\hline 2000 & $412,332.00$ & & 3666.60 & - & 3666.60 \\
\hline 2001 & $431,783.20$ & & 1314.00 & - & 1314.00 \\
\hline 2002 & $451,785.70$ & & 4310.90 & - & 4310.90 \\
\hline 2003 & $495,007.20$ & & 9954.80 & - & 9954.80 \\
\hline 2004 & $528,576.05$ & & $11,353.80$ & - & $11,353.80$ \\
\hline 2005 & $561,931.39$ & & $28,504.80$ & - & $28,504.80$ \\
\hline 2006 & $595,821.62$ & & - & $16,450.20$ & $16,450.20$ \\
\hline 2007 & $634,251.27$ & & - & $22,850.20$ & $22,850.20$ \\
\hline 2008 & $672,202.56$ & & - & $42,753.06$ & $42,753.06$ \\
\hline 2009 & $718,977.34$ & & - & $58,215.66$ & $58,215.66$ \\
\hline 2010 & $775,525.70$ & & - & $52,867.50$ & $52,867.50$ \\
\hline 2011 & $834,160.00$ & & - & $53,319.90$ & $53,319.90$ \\
\hline
\end{tabular}

Source: Central Bank of Nigeria, Statistical Bulletin, 2010 and 2011.

Notes:

1. Rural banking scheme commenced in 1982 and ended 1991

2. Community bank scheme commenced in 1992 and all surviving community banks transformed to microfinance banks on $31^{\text {st }}$ Dec. 2006

3. Implementation of liberalization policy relating to operations of existing commercial banks in 1992 led to abrogation of requirements for mandatory sectoral credit allocation and enforcement of limitation of commercial banks' rural branch credits to environment/community based enterprises conceptualized as micro enterprises for policy purposes.

Real gross domestic product serves as the relevant economic growth indicator. Several studies including Murty et al (2012), Nuno (2012) and Aliero et al (2013) among others have employed financial intermediation indicators and/or sectoral distribution of credits within the domestic economy as valuable proxies with significant results. However, 
Demetriades and Hussein (1996) argue that private sector credit reflects quantity and quality of finance as well as the financing role of deposit money banks. Accordingly, it excludes all public sector credits and as noted by Levine and Zervous (1998), private sector credits are provided under more stringent credit conditions, thereby having the potentials of generating more qualitative investment results. Consequently, we contend that the annually aggregated cash related credit exposures of these formal private sector led micro credit institutions to the domestic economy in Nigeria can also, constitute reliable basis for exploration of empirical interrelationships and direction of causality between their microcredit operations and the domestic economy.

\subsection{Model Specifications}

In Nigeria, micro credits are preferably allocated to entrepreneurial ventures within the operational domain of the micro credit institutions. Essentially the micro credits employed for this study are private sector related and as Crowley (2008) argues, credits to the private sector have relatively greater impact on economic growth than those allocated to the public (government) sector. Following Shabri and Majid (2008) as well as Aliero, Abdullahi and Adamu (2013), we propose the following model to establish the relationship between micro finance institutions' credits and economic growth;

Where;

$$
Y=\beta_{o}+\beta_{1} M F C_{t}+\mu_{t}
$$

$\mathrm{Y}=$ Real gross domestic product

$\beta_{\mathrm{o}}=$ Slope or constant parameter

$\mathrm{MFC}_{\mathrm{t}}=$ Microfinance institutions credit at time t.

$\beta_{1}=$ Vector coefficient of microfinance institutions credit

$\mu_{\mathrm{t}}=$ Stochastic term.

Maddala (2007) as well as Gujarati and Porter (2009), demonstrate that most macro economic time series data have problems of non-stationarity since the data set may be associated with either problems of time-varying mean, time-varying variance or both, implying that time series data may have unit root properties. Consequently, the stationarity associated with given set of time series data could be evaluated through the conduct of a unit root test in order to determine the stationarity or otherwise of the time series variables.

\subsection{Stationarity Test}

Stationarity test serves as a prerequisite for co-integration procedure for each time series variable over a sample period. Popularized by the works of Engle and Granger, Maddala (2007), notes that the tool has gained wide acceptance for analysis of time series data with stochastic trends. Unit root property of each of the time series data needs to be ascertained to confirm their non-stationary or stationary state as a prerequisite for inclusion in co-integration analysis and evaluation of long-run relationships. The existence of a unit root implies non-stationarity of the affected time series data, while non-existence of a unit root confirms stationarity of the particular time series data which makes it suitable for inclusion in co-integration analysis.

For detection of the presence or otherwise of a unit root in a time series data, we consider a variable y that has a unit root which is articulated by a first order autoregressive equation AR (1) as follows;

$$
Y_{t}=\propto Y_{t-1}+\mu_{t}
$$

Where;

$\mathrm{Y}_{\mathrm{t}}=$ Real GDP at time $\mathrm{t}$.

$\alpha=$ Coefficient of one period lagged value of real GDP

$\mathrm{Y}_{\mathrm{t}-1}=$ One period lagged value of real GDP.

$\mu_{\mathrm{t}}=$ White noise error term which is statistically assumed independent and randomly distributed with zero mean, constant variance and is serially uncorrelated.

Consequently, the modeling procedure for testing the existence of unit root of a time series data is specified generally as follows;

$$
\Delta Y_{t}=\alpha_{0}+\alpha_{2} Y_{t-1}+\sum_{i=1}^{p} \delta_{i} \Delta Y_{t-1}+\epsilon_{i}
$$


Where;

$\mathrm{Y}=$ Variable of choice

$\alpha_{0}=$ Intercept

$\Delta=$ First difference operator

$\alpha_{i}=($ for $\mathrm{i}=1$ and 2$)$ and $\delta I($ for $\mathrm{i}=1,2, \ldots$ P) are constant Parameters

$\sum \mathrm{i}=$ Stationary stochastic process

$\rho=$ Number of lagged terms chosen by Akaike information criterion (AIC) to ensure that $\sum i$ is white noise.

Following equation (3), the implied hypotheses for testing would consist of the following;

$\mathrm{H}_{\mathrm{o}}: \quad \alpha_{2}=\mathrm{O}$, ie there is a unit root - the time series is non-stationary.

$\mathrm{H}_{1}: \quad \alpha_{2} \neq 0$ ), ie there is no unit root - the time series is stationary.

As a decision rule, if the absolute values of the calculated Augmented Dickey-Fuller (ADF) test statistic are relatively higher than those of Mckinnon's critical values, then the null hypothesis $\left(\mathrm{H}_{\mathrm{o}}\right)$ is accepted, implying that a unit root exists. Further, it implies that a unit root exists in $\mathrm{Y}_{\mathrm{t}-1}$ and $\Delta \mathrm{Y}_{\mathrm{t}-1}$, which connotes that the time series are non-stationary and are not integrated at level (of order zero), expressed as I(o). A rejection of the null hypothesis implies that the time series data are stationary. However, a failure to reject the null hypothesis methodologically leads to a further conduct of the stationarity test on differenced variant of each of the time series data. By implication, further differencing should be conducted to achieve stationarity of the study's time series data for the null hypothesis to be correspondingly rejected. The generalized model for further differencing could be achieved through a modification of equation (3) to include the second differences on lagged first, as well as the $\mathrm{K}$ lags of the second differences as follows;

$$
\Delta^{2} Y_{t}=\psi_{1} \Delta Y_{t-1}+\sum_{i=1}^{p} \theta_{i} \Delta^{2} Y_{\mathrm{t}-1}+\varepsilon_{\mathrm{t}}
$$

In this differenced situation, the hypotheses to be tested are

$\mathrm{H}_{\mathrm{o}}=\psi_{1}=0$, ie, there is a unit root, implying that the time series is non-stationary.

$\mathrm{H}_{1}=\psi_{1} \neq 0$, ie, there is no unit root, implying that the time series is stationary.

Broadly, if the time series prove stationary on first differencing, they are said to be co-integrated of order one, expressed as 1(1). If stationarity is achieved on second differencing, the time series are said to be integrated of order two ie, 1(2). Generally, the lagged variables are introduced into the models to function as control variables and also, to recognize or capture the dynamic nature of the study variables - micro credits and real gross domestic product (Akpansung and Babalola, 2011).

\subsection{Estimation of Long-Run Relationship between Micro Credits and Economic Growth}

Estimation of the long-run dynamic relationship between micro credits and Nigeria's economic growth was executed through employment of the Autoregressive Distributed Lag Bound approach. Popularized by the works of Pesaran and Shin (1996) and Pesaran and Pesaran (2001), ARDL technique has significant advantages. The approach can be employed even when the time series data are non-stationary and still, allow for conduct of inferences which is not possible under the alternative co-integration approach. This advantage offers a wide range of opportunities to conduct the estimation regardless of whether the time-series regressors are stationary at 1(0), 1(1) or both. Further, ARDL is associated with good small sample properties implying that ARDL still provides quality results when the sample size is small and lastly, even if the series variables are fractionally integrated.

Accordingly, the Autoregressive Distributed Lag (ARDL) Model employed for this study is written as follows;

$$
\begin{gathered}
\Delta_{\mathrm{ln}} \mathrm{RGDP}_{\mathrm{t}}=\delta_{o}+\delta_{1} R G D P_{t-1}+\delta_{2} M F C_{t-1}+\sum \delta_{3} \Delta l_{n} R G D P_{t-1}+\sum \delta_{4} \Delta l_{n} M F C_{t-1}+\mu_{1 t} \\
\Delta_{\mathrm{ln}} \mathrm{MFC}_{\mathrm{t}}=\propto_{o}+\propto_{1} I_{n} M F C_{t-1}+\propto_{2} I_{n} R G D P_{t-1}+\sum \propto_{3} \Delta l_{n} M F C_{t-1}+\sum \alpha_{4} \Delta l_{n} R G D P+\mu_{2 t}
\end{gathered}
$$

Where; 
$R G D P_{t}=$ Real gross domestic product at time t.

$M F C_{t}=$ Micro finance institutions' credits at time t.

$\Delta \mathrm{l}_{\mathrm{n}} \mathrm{RGDP}=$ Differenced natural Log value of RGDP

$\delta_{0}$ and $\alpha_{0}=$ Constant parameters.

$\Delta \mathrm{l}_{\mathrm{n}} \mathrm{MFC}_{\mathrm{t}}=$ Differenced natural log value of microfinance institutions' Credits at time $\mathrm{t}$.

$\Delta \mathrm{l}_{\mathrm{n}} \mathrm{RGDP}_{\mathrm{t}-1}=$ First Lag values of the differenced natural log value of RGDP

$\Delta \mathrm{l}_{\mathrm{n}} \mathrm{MFC}_{\mathrm{t}-1}=$ First Lag values of the differenced natural lag value of microfinance institutions' credits

$\mu_{\mathrm{t}}=$ Error term.

\subsection{Error Correction Model (ECM)}

Essentially, the error correction dynamic of the model is represented by the term with summation signs $\left(\sum\right)$, while the corresponding long-run relationship of the model is represented by the term with $\left[\delta_{5}\right]$ which corresponds to the second part of the model.

\section{Presentation of Results}

In analyzing the empirical relationship between micro credits and Nigeria's economic growth, this section starts with analysis of the descriptive statistics presented in table 2, below;

Table 2. Descriptive statistics on real GDP and microfinance credits

\begin{tabular}{lccccc}
\hline \multicolumn{1}{c}{ Variables } & Obsv & Mean & Std. Dev. & Minimum & Maximum \\
\hline Real GDP & 30 & 428654.4 & $168,702.9$ & 227254.7 & 834160 \\
\hline Micro Finance Credits & 30 & $11,113.44$ & $17,726.06$ & 39.50 & $58,215.66$ \\
\hline
\end{tabular}

Source: Authors' Computations using E-VIEWS 7.1

Deriving from the data in table 1, analysis of the descriptive statistics shown in table 2 above indicates that the number of observations is 30 representing the 30 year period the study covers. The means of Real GDP and Microfinance institutions' credits were computed as 428,654.40 and 11,113.44 millions of Naira respectively. At the same time, while the maximum amounts for Real GDP and microfinance institutions' credits were N834,160 (M) and N58,215.66 (M), their minimum values were N227,254.70 (M) and N39.50 (M) respectively. Of interest also, is the significant disparity in the computed values of their standard deviations shown as 168,702.90 and 17,726.06 for Real GDP and microfinance institutions' credits respectively.

\subsection{Stationarity Tests}

To analyze the relationship between microfinance institutions' credits and economic growth in Nigeria, the study commences with the conventional test for stationarity of the series variables by employment of the Augmented Dickey - Fuller (ADF) unit root test which results are presented in table 3 below;

Table 3. Results of Augmented Dickey-Fuller (ADF) unit root test

\begin{tabular}{lccc}
\hline \multicolumn{1}{c}{ Variable } & Level value & Differenced value & Conclusion \\
\hline LRGDP & 0.209807 & $-5.120165^{* *}$ & $1(1)$ \\
\hline LMFC & -1.561732 & $-6.367844^{* *}$ & $1(1)$ \\
\hline
\end{tabular}

Source: Authors' Computations using E-VIEWS 7.1 Software

Note: ${ }^{* *}$, indicates significance at $1 \%$.

We have earlier asserted that time series analysis conventionally commences with unit root-test in order to ascertain the stationarity attributes of the associated series variables. Accordingly, table 3 above presents the summarized results of the ADF unit root test on both level and first differenced values of the natural Log of Real GDP (LRGDP) and natural Log of Microfinance institutions' credits (LMFC) as specified in equation (3). The computed results reveal that the series variables are not stationary at their levels. However, stationarity of the series variables was achieved after taking the first difference of the series variables at $1 \%$, which obviously implies that they are co-integrated of order one, conventionally denoted as 1 (1). The achievement of stationarity therefore, serves as prerequisite for execution of co-integration test, which result is discussed next. 


\subsection{Bound F-Test for Co-integration}

Having achieved stationarity of the series variables, co-integration tests were conducted in accordance with equations (5) and (6) earlier stated in order to ascertain the nature of long run relationship among the study variables based on the series data. Table 4 below shows the results of the Bound $\mathrm{F}$ - test for Co-integration along with the asymptotic critical values;

Table 4. Results of bound F-test for cointegration

\begin{tabular}{lcc}
\hline \multicolumn{1}{c}{ Dependent Variable } & Function & F-statistics \\
\hline LRGDP & LRGDP (RGDP/MFC) & 0.706340 \\
\hline LMFC & LMFC (MFC/RGDP) & 5.363813 \\
\hline Asymptotic Critical Values & $5 \%$ & $10 \%$ \\
\hline Lower Bound & 3.79 & 3.17 \\
\hline Upper Bound & 4.85 & 4.14 \\
\hline
\end{tabular}

Source: Authors' Computations using E-views 7.1 Software, relying on Persan Critical Value Bounds for F-statistics.

The results of Bound F-test for Co-integration presented in table 4 above show that co-integration is only present when we employ LMFC as the dependent variable. This is because the computed F of LMFC (MFC/RGDP) with value of 5.363813 is higher than the upper bound critical value at both $5 \%$ and $10 \%$ (i.e. $5.5363813>4.85$ and 4.14 respectively). On the contrary, no co-integration was found using LRGDP as dependent variable since the computed $\mathrm{F}$ for LRGDP (RGDP/MFC) with value of 0.706340 is lower than both the lower bound values of 3.79 and 3.17 for $5 \%$ and $10 \%$ levels of significance. In the same vein, the $\mathrm{F}$ value of 0.706340 is equally lower than the upper bound values of 4.85 and 4.14 for $5 \%$ and $10 \%$ levels of significance.

\subsection{Estimation of Long-Run Co-efficient Using ARDL Approach}

Based on the fact that a co-integration relationship has been established between the series variables (when MFC is used as dependent variable), it allows us to establish an Autoregressive Distributive Lag (ARDL) model in order to estimate the long-run relationship between microfinance institutions' credits and Nigeria's economic growth. The results of the ARDL test are presented in Table 5 below;

Table 5. Estimated long-run coefficient using ARDL approach

\begin{tabular}{lcccc}
\hline \multicolumn{1}{c}{ Regressor } & Coefficient & Std Error & T-ratio & P-value \\
\hline $\begin{array}{l}\text { Dependent } \\
\text { LRGDP }\end{array}$ & variable: & & & \\
\hline LMFC & 0.008147 & 0.002740 & 2.973585 & 0.0063 \\
\hline
\end{tabular}

$\mathrm{R}^{2}=0.176$

$\mathrm{DW}=2.202$

Source: Authors' Computations Using E-VIEWS 7.1

From Table 5, the estimated long-run coefficient using ARDL approach indicates that the long-run elasticity of LRGDP is positive (0.008147) which agrees with our apriori expectation of positive relationship between microfinance institutions' credits and economic growth in Nigeria. Accordingly, the results show that the long-run positive impact of microfinance credits (MFC) on real gross domestic product (RGDP) is 0.008 , which is significant at $1 \%$ level. This implies that for any $1 \%$ increase in microfinance institutions' credits, Nigeria's RGDP will increase by $0.8 \%$ correspondingly. Further, the coefficient of determination $\left(\mathrm{R}^{2}\right)$ value of 0.1762 implies that variations in microfinance institutions' credits account for $17.6 \%$ of variations in Nigeria's real gross domestic product. The Durbin-Watson value of 2.202 is within acceptable range.

\subsection{Causality Tests}

One of the cardinal objectives of this study is to evaluate the direction of causality between microfinance institutions' credits and economic growth in Nigeria. Granger causality tests provide veritable tool for this investigation. On the essence of Granger causality approach, Okpala (2011:141) writes thus:

The Granger (1969) approach to the question of whether $X$ causes $Y$ is to see how much of the current $Y$ that can be explained by past values of $Y$ and also, to see whether adding lagged values of $X$ can improve the explanation. $Y$ is 
said to be Granger - caused by $X$ if $X$ helps in the prediction of $Y$, or equivalently, if the coefficients of the lagged $X$ 's are statistically significant.

Accordingly, the Granger test is fundamentally predicated on the following regression analysis:

Where;

$$
\begin{aligned}
& Y_{t}=\beta_{o}+\sum \beta_{i} Y_{t-i}+\sum \beta_{\mu} X_{t-i}+\mu_{t} \\
& Y_{t}=\propto_{o}+\sum \propto_{i} X_{t-i}+\sum \propto_{\mathrm{i}} Y_{\mathrm{t}-\mathrm{i}}+V_{\mathrm{t}}
\end{aligned}
$$

$Y_{t}$ and $X_{t}$ are the time series variables to be tested. $\mu_{t}$ and $V_{t}$ constitute the idiosyncratic terms that capture all variations in $\mathrm{Y}_{\mathrm{t}}$ and $\mathrm{X}_{\mathrm{t}}$ not included in the lagged values.

Table 6 below presents the results of Granger Causality test:

Table 6. Results of Granger Causality Test

\begin{tabular}{lcccc}
\hline \multicolumn{1}{c}{ Null Hypotheses } & Lags & Obs & F-statistics & P-value \\
\hline LMFC does not Granger cause LRGDP & 2 & 28 & 1.55864 & 0.2318 \\
\hline LRGDP Does Not Granger cause LMFC & 2 & 28 & 10.7544 & 0.0005 \\
\hline
\end{tabular}

Source: Authors' Computations Using E-VIEWS 7.1

The results of Granger-Causality test indicate that there is no bi-directional causality between microfinance institutions' credits and Nigeria's gross domestic product. Unidirectional causality is only found between Nigeria's real gross domestic product and microfinance institutions' credits with causality flowing from real gross domestic product to microfinance credits. Consequently, with F-statistic value of 10.7544 and probability value of 0.0005 , we reject the null hypothesis of no causality from Nigeria's real gross domestic product to microfinance credits. At the same time, the null hypothesis is accepted in respect of flow of causality from micro finance credits to real gross domestic product, since it has a probability of 0.2318 , which is far below critical value of 0.05 .

\section{Discussions, Conclusions and Policy Recommendations}

Although empirical literature sparsely prevails currently on the influence of micro credits on Nigeria's economic growth, however, the results of this study tend to come to the fore when microfinance is viewed as part of Nigeria's deposit money banking system. However, the results of this study represent a significant improvement over the findings of Oluyombo (2011) in terms of Nigerian data and reasonably, reinforce the findings of Sharma and Puri (2013) on the international scene with respect to Indian data.

From the findings, we conclude that there exists a long-run relationship between microfinance programme credits in Nigeria and the nation's economic growth. Secondly, causality is unidirectional and flows from economic growth to microfinance programme credits in Nigeria. To that extent, microfinance institutions are playing demand following roles and resultantly, largely service entrepreneurship ventures. By implication, the growing Nigerian economy currently provides significant range of business opportunities which the microcredit institutions can tap with appropriate products. As a developing economy, various state policy initiatives towards making the private sector the engine of economic growth and employment exist, all of which lend valuable support and opportunities for microcredit operations.

Following the results and conclusions reached above, we recommend that microfinance institutions in Nigeria should be encouraged by the regulators to increase the quantum of micro credits and also, conduct relevant researches to develop more of long-tenured credit products as opposed to the present regime of short tenured and self-liquidating credit products. These measures will not only assist in achieving a higher rate of economic growth in the long-run, but will also, enhance the contributions of microcredit institutions to Nigeria's economic growth through the vehicle of appropriate credit products to meet the needs of diversified entrepreneurial investment projects in the Nigerian economy.

\section{References}

Adegbite, O. (1985). Interview with Business Times, Lagos, July 29.

Adeyemi, K. S. (2007, Dec). Institutional Reforms for Efficient Microfinance Operations in Nigeria. Union Digest, $11(3 \& 4)$.

Agene, C.A. (2011). Microfinance Banking: Principles and Practice. Ibadan, Daily Graphics. 
Akinboyo, O. L. (2007, Jan./March). Microfinance Banks: Unlocking The Potentials of Micro Business Activities of The Nigerian Rural Economy. The Bullion, 31(1).

Akinrisimi, A. (1986). Interview with Business Times, Lagos, Sept. 22.

Akpansung, A. O., \& Babalola, S. J. (2011, Dec). Banking Sector Credit and Economic Growth in Nigeria: An Empirical Investigation. CBN Journal of Applied Statistics, 2(2).

Aliero, H. M., Abdullahi, Y. Z., \& Adamu, N. (2013, Jan). Private Sector Credit and Economic Growth Nexus in Nigeria: An Autoregressive Distributed Lag Bound Approach. Mediterranean Journal of Social Sciences, 4(1.1). http://dx.doi.org/10.5901/mjss.2013.v4n1p83

Crowley, J. (2008). Credit Growth in the Middle East, North Africa and Central Asia Region. IMF Working Paper, No. 08/184. http://dx.doi.org/10.5089/9781451870428.001

Dauda, R. O. S. (2007, June). The Role of Community Banking System In Nigeria's Development Process: An Appraisal. Journal of Banking, 2(1).

Demetriades, P. O., \& Hussein, K. (1996). Does Financial Development Cause Economic Growth? Time Series Evidence from 16 Countries. Journal of Development Economics, 15. http://dx.doi.org/10.1016/S0304-3878(96)00421-X

Ezirim, C. B., Adebajo, R., \& Ogunbiyi, S. (2008). Microfinance and Rural Economic Development: Some Theoretical Issues. In Nwikina. C. G. and Mawo, J. G. (Eds,), Microfinance and Poverty Alleviation in Nigeria - Strategies and Challenges. Port Harcourt, Harrisco Press.

Gujarati, D. N., \& Porter, D. C. (2009). Basic Econometrics. Boston, McGraw Hill.

Helms, B. (2006). Access for All: Building Inclusive Financial Systems, Consultative Group to assist the Poor. Washington, World Bank. http://dx.doi.org/10.1596/978-0-8213-6360-7

Ibene, A. (1981). Banks Have No Cause To Complain On Rural Banking Scheme. Business Times, April 20.

Kuforiji, A. (1985). Chairman's Statement, (Annual Accounts). Lagos, United Bank for Africa Plc.

Livine, R., \& Zervos, S. (1998). Stock Markets, Banks and Economic Growth. American Economic Review, 88.

Maddala, G. S. (2007). Introduction to Econometrics. New Delhi, John Willey.

Mckinnon, R. I. (1973). Money and Capital in Economic Development. Washington D.C, Brookings Institute.

Murty, K. S., Sailaja, K., \& Demissie, W.M. (2012). The Long Run Impact of Bank Credit on Economic Growth in Ethiopia: Evidence from Johansen's Multivariate Co-Integration Approach. European Journal of Business and Management, 4(14).

Nuno, C. L. (2012). Bank Credit and Economic Growth: A dynamic Panel Data Analysis. The Economic Research Guardian, 2(2).

Nwakanma P.C., \& Nnamdi, I.S. (2011). Marketing of Financial Services in Nigeria: Theory and Developments. Owerri, Strammac Communications Consult.

Nwankwo G. O. (1985). The Nigerian Financial System. London, Macmillan Publishers.

Okpara, G. C. (2010). Microfinance Banks and Poverty Alleviation in Nigeria. Journal of Sustainable Development in Africa, 12(6).

Okpara, G. C. (2011). Analysis of The Efficiency and Predicative power of The Nigeria Stock Market. (1984 - 2009), Unpublished Ph.D Dissertation, Abia State University, Uturu, Abia State, Nigeria.

Oluyombo, O. O. (2011). The Impact of Microfinance Bank Credits on Economic Development of Nigeria (1992 2006). International Journal of Development and Management Review, 6(1).

Pesaran, H. M., \& Pesaran, C. (2001). Bound Testing Approach to the Analysis of Level Relationships. Journal of Applied Econometrics, 16. http://dx.doi.org/10.1002/jae.616

Pesaran, H. M., \& Shin, Y. (1996). Autoregressive Distributed Lag Modeling to Cointegration Analysis, DAE Working Paper Series, No. 9514, Department of Applied Economics, University of Cambridge.

Quinones, B., \& Remenyi, J. (2000). Microfinance and Poverty Alleviation: Case Studies from Asia and the Pacific. New York, Pinter. 
Rousseau, P. L., \& Wachtel, P. (2002). Inflation Thresholds and the Financial-Growth Nexus. Journal of International Money and Finance, 21. http://dx.doi.org/10.1016/S0261-5606(02)00022-0

Rousseau, P. L., \& Wachtel, P. (2011). What Is Happening to the Impact of Financial Deepening on Economic Growth? Economic Inquiry, 49(1). http://dx.doi.org/10.1111/j.1465-7295.2009.00197.x

Schumpeter, J. A. (1934). The Theory of Economic Development. Cambridge Mass, Harvard University Press.

Seibeil, H.D. (2000, June). Agricultural Development Banks: Close them OR Reform them? F $\alpha D, 37(2)$.

Shabri, M., \& Majid, A. (2008). Does Financial Development Matter for Economic Growth in Malaysia? An ARDL Bound Testing Approach. Journal of Economic Cooperation, 29.

Sharma, G.L., \& Puri, H. (2013, April-June). An Empirical Testing of Relationship between Microfinance and Economic Growth in India. Journal of Indian Research, 1(2).

Shaw, E. (1973). Financial Deepening In Economic Development. London, Oxford University Press.

Shaw, E.S. (1976). Financial Repression and Liberalization. In Meier, G.M. (Ed.), Leading Issues in Economic Development. New York, Oxford University Press.

Umesi, R. (1981). Banks Complain About Rural Banking Scheme. Business Times, April, 6.

Umoh, P. N. (1984, Sept). Financial Development and the Rural Banking Scheme in Nigeria. The Banker, 134(703), London, Institute of Bankers.

World Bank. (1990). World Development Report 1999: Poverty. Oxford, Oxford University Press.

World Bank. (1993). Poverty Reduction Hand Book. Washington D.C.: The World Bank.

Yunus, M. (2003). Banker to the Poor: Micro-lending and the Battle against World Poverty. New York, Public Affairs.

Yunus, M. (2008). Creating a World without Poverty: Social Business and the Future of Capitalism. New York, Public Affairs. 